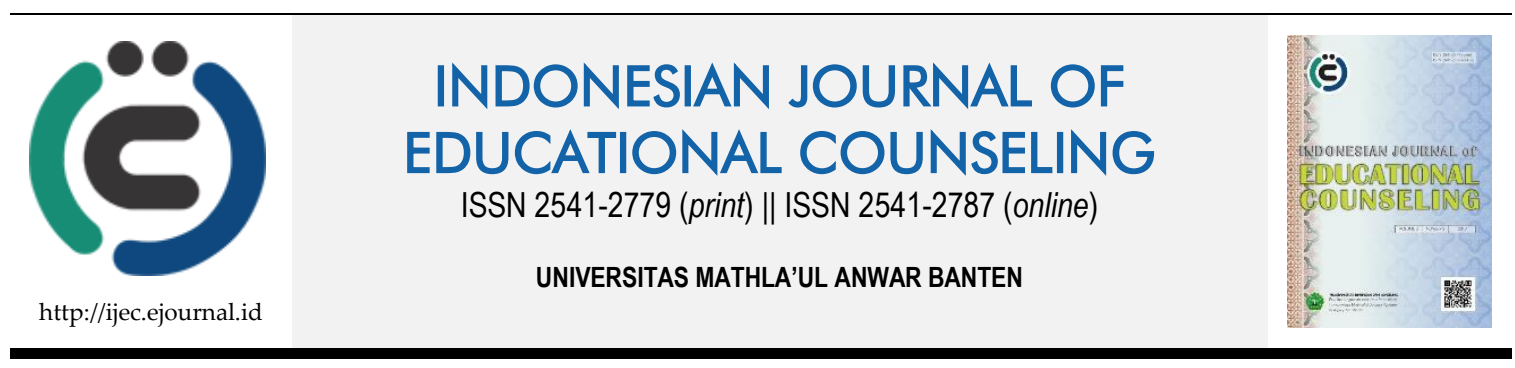

Research Based Article

\title{
KRR sebagai Program Pengembangan Perilaku Seksual Sehat Remaja pada Revolusi Industri 4.0
}

\author{
Hardi Santosa' ${ }^{1}$, Syamsu Yusuf ${ }^{2}$, Ilfiandra ${ }^{3}$
}

${ }^{1}$ STKIP Muhammadiyah Pringsewu, 2, 3 Universitas Pendidikan Indonesia

\begin{tabular}{|c|c|}
\hline Article History & ABSTRACT \\
\hline $\begin{array}{l}\text { Received: } 25.03 .2019 \\
\text { Received in revised form: } \\
\text { 01.04.2019 } \\
\text { Accepted: } 10.04 .2019 \\
\text { Available online: } 05.08 .2019\end{array}$ & $\begin{array}{l}\text { KRR AS A PROGRAM FOR DEVELOPING HEALTHY SEXUAL BEHAVIOR IN } \\
\text { INDUSTRIAL REVOLUTION 4.0. Adolescents are in a transition period } \\
\text { characterized by drastic physical changes, psychological instability, and adjustment } \\
\text { of new social environments. The era of industrial revolution 4.0, which was marked } \\
\text { by the acceleration of information and digitalization of life increasingly added to the } \\
\text { challenges of adolescents to be able to achieve the task of sexual development. When } \\
\text { adolescents fail to carry out their sexual development tasks, they can have negative } \\
\text { implications for adolescent sexual behavior. Understanding and awareness of } \\
\text { adolescent reproductive health (KRR) can be an alternative in developing healthy } \\
\text { and responsible sexual behavior. This study aims to test KRR as a mode of } \\
\text { intervention to develop healthy sexual behavior in adolescents. The research method } \\
\text { uses a mixed-method by combining quantitative and qualitative data that supports } \\
\text { each other. The research population of tenth-grade high school students was } 250 \\
\text { students with a sample of } 30 \text { people. Purposive sampling technique by considering } \\
\text { the pretest score on the average class is taken into consideration in the selection of } \\
\text { samples-data collection by providing a scale of sexual behavior, observation, and } \\
\text { interviews. The results of the study show: (1) in general the sexual behavior of } \\
\text { students is at a level of caution towards the need for development; (2) The KRR } \\
\text { consists of nine guidance content with an audio-visual based group guidance } \\
\text { strategy; and (3) the KRR program is effective in developing healthy sexual behavior } \\
\text { in adolescents. }\end{array}$ \\
\hline
\end{tabular}

KEYWORDS: Adolescent Sexual Behavior, KKR, the Industrial Revolution 4.0.

DOI: 10.30653/001.201933.104

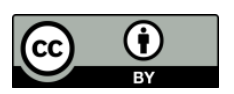

This is an open access article distributed under the terms of the Creative Commons Attribution 4.0 International License, which permits unrestricted use, distribution, and reproduction in any medium, provided the original work is properly cited. (c) 2019 Hardi Santosa, Syamsu Yusuf, Ifiandra.

\section{PENDAHULUAN}

Masa remaja merupakan segmen kehidupan yang sangat penting dalam siklus perkembangan individu, karena dapat diarahkan kepada masa dewasa yang sehat (Kaczman \& Riva, 1996, dalam Yusuf, 2007). Adapun yang menjadi tanda-tanda dimasukinya masa remaja menurut Salman dan Pikunas (Yusuf, 2007) antara lain: (1) berkembangnya sikap dependen kepada orang tua kearah independen, (2) minat

${ }^{1}$ Corresponding author's address: Program Studi Bimbingan dan Konseling, STKIP Muhammadiyah Pringsewu; Jl. Makam KH. Ghalib No.112, Pringsewu Utara, Kec. Pringsewu, Kabupaten Pringsewu, Lampung 35373, Indonesia; Email: santosahardi.2013@gmail.com 
seksualitas; dan (3) kecenderungan untuk merenungkan atau memperhatikan diri sendiri, niali-nilai etika, dan isu-isu moral.

Dalam kajian psikologi perkembangan, secara fisik masa remaja ditandai dengan matangnya organ-organ seksual. Remaja pria mengalami pertumbuhan pada organ testis, penis, pembuluh mani, dan kelenjar prostat. Matangnya organ-organ ini memungkinkan remaja pria mengalami mimpi basah. Sementara remaja wanita ditandai dengan tumbuhnya rahim, vagina, dan ovarium. Ovarium menghasilkan ova (telur) dan mengeluarkan hormon-hormon yang diperlukan untuk kehamilan, dan perkembangan seks sekunder. Matangnya organ-organ seksual ini memungkinkan remaja wanita mengalami menarche (menstruasi/haid pertama).

Fase remaja ini merupakan masa terjadinya banjir hormon, yaitu zat-zat kimia yang sangat kuat, yang disekresikan oleh kelenjar-kelenjar endoktrin dan dibawa keseluruh tubuh oleh aliran darah. Konsentrasi hormon-hormon tertentu meningkat secara dramatis selama masa remaja, seperti hormon testosteron dan estradiol. Testosteron merupakan hormon yang berkaitan dengan perkembangan alat kelamin, pertambahan tinggi, dan perubahan suara pada anak laki-laki. Sedangkan Estradiol adalah suatu hormon yang berkaitan dengan perkembangan buah dada, rahim, dan kerangka pada anak perempuan (Santrock, 2003).

Seiring dengan berkembangnya organ-organ reproduksi pada masa remaja menuju kematangan seksual, Sigmund Freud (Hurlock, 1998) mengemukakan bahwa pada masa remaja libido atau energi seksual remaja menjadi hidup, yang tadinya laten pada masa pra remaja. Oleh karena itu muncul juga hasrat dan dorongan untuk menyalurkan keinginan seksualnya. Mengingat dorongan atau hasrat untuk melakukan hubungan seksual pada remaja selalu muncul, maka perlu ada penyaluran yang sesuai (menikah) untuk menyalurkan dorongan-dorongan tersebut. Namun apabila remaja merasa belum mampu untuk menikah maka perlu dilakukan usaha untuk memberi pengertian dan pengetahuan yang komprehensif mengenai hal tersebut sehingga remaja dapat terampil mengambil keputusan yang tepat, benar dan bertanggung jawab dalam menyikapai dorongan-dorongan seksualnya. Jika keinginan seksual yang muncul secara alamiah ini mampu dikelola dengan baik, maka akan memungkinkan membantu perkembangan remaja dalam menjalankan tugas-tugas perkembangannya secara lebih optimal sehingga dapat tumbuh menjadi pribadi-pribadi yang berkualitas dan mampu mencapai citacitanya.

Keinginan untuk menyalurkan dorongan seksual dan timbulnya rasa ingin tahu terhadap masalah seksual sangat penting dalam pembentukan hubungan baru yang lebih matang dengan teman sebaya maupun lawan jenis (Hurlock,1998: 226). Timbulnya hasrat seksual inilah salah satu faktor yang mendorong perilaku seksual baik dengan lawan jenis maupun sesama jenis. Jika dorongan rasa ingin tahu yang muncul secara alamiah ini tidak diarahkan dengan baik, apalagi remaja salah mencari informasi tentang seks maka akan dapat berdampak buruk. Dampak buruk ini dapat menghambat belajar siswa bahkan gagal dalam sekolah sehingga juga akan berdampak pada kegagalan cita-cita hidupnya. Sebagai contoh bagi remaja yang salah mencari informasi pengetahuan seks melalui tayangan-tayangan video porno, majalah orang dewasa dan media-media pornografi lainnya maka akan berdampak pada kerusakan otak remaja yang mengakibatkan semakin menurunnya daya ingat mereka, bahkan berdasarkan penelitian yang dilakukan oleh seorang dokter ahli bedah saraf dari rumah sakit San Antonio Amerika serikat dampak kerusakan otak ini melebihi dari pengguna narkoba. Dalam penelitiannya Donald L. 
Hilton Jr, menyatakan bahwa materi pornografi secara terus menerus menyebabkan adiksi atau kecanduan. Adiksi menyebabkan otak bagian tengah depan yang disebut ventral tegmental area (VTA) secara fisik mengecil. Penyusutan jaringan otak yang memproduksi dopamine (bahan pemicu rasa senang) menurut dia menyebabkan kekacauan kerja neurotransmitter, yakni zat kimia otak yang berfungsi sebagai pengirim pesan. Pornografi menimbulkan perubahan konstan pada neurotransmitter dan melemahkan fungsi kontrol. Ini yang membuat orang-orang yang sudah kecanduan tidak bisa lagi mengontrol perilakunya (Pikiran Rakyat, 3 Maret 2009).

Pengetahuan remaja Indonesia tentang kesehatan reproduksi dan seksualitas sangat memperihatinkan, Fenomena-fenomena ini terungkap dari beberapa penelitian dan pengalaman para ahli dalam menangani permasalahan perilaku seksual remaja, seperti yang dikemukakan oleh Boyke Dian Nugraha, DSOG, ahli kebidanan dan penyakit kandungan pada RS Dharmais, menyatakan bahwa informasi seks dari teman, film, atau buku, yang hanya setengah-setengah tanpa pengarahan, mudah menjerumuskan. Apalagi kalau si anak tidak tahu risiko melakukan hubungan seksual pranikah. Lebih lanjut, Boyke memaparkan dari data yang dikumpulkannya menunjukkan $16-20 \%$ dari remaja yang berkonsultasi kepadanya telah melakukan hubungan seks pranikah, dalam catatannya itu rata-rata remaja memiliki pengetahuan yang kurang tentang seks. Dia mencontohkan ada remaja yang berpendapat, kalau hanya sekali bersetubuh, tidak bakal terjadi kehamilan. Cara lain seperti meloncat-loncat atau mandi sampai bersih segera setelah melakukan hubungan seksual bisa mencegah kehamilan, berciuman atau berenang di kolam renang yang "tercemar" sperma bisa mengakibatkan kehamilan, mimpi basah dikira mengidap penyakit kotor, kecil hati gara-gara ukuran penis kecil, sering melakukan onani bisa menimbulkan impotensi. Hal ini tampak jelas bahwa Pengetahuan seks yang hanya setengah-setengah tidak hanya mendorong remaja untuk mencoba-coba, tetapi juga bisa menimbulkan salah persepsi.

Rendahnya pengetahuan tentang kesehatan reproduksi pada remaja ini juga terungkap dalam penelitian yang dilakukan oleh pusat informasi dan konseling kesehatan reproduksi remaja (PIK-KRR) yang mengungkap bahwa remaja perempuan dan laki-laki usia 15-24 tahun yang tahu tentang masa subur baru mencapai $29 \%$ dan $32,3 \%$. Remaja perempuan dan remaja laki-laki yang mengetahui risiko kehamilan jika melakukan hubungan seksual sekali masing-masing baru mencapai $49,5 \%$ dan $45,5 \%$. Remaja perempuan dan remaja laki-laki usia 14-19 tahun yang mengaku mempunyai teman pernah melakukan hubungan seksual pra nikah masing-masing mencapai 34,7\% dan 30,9\% sedangkan remaja perempuan dan laki-laki usia 20-24 tahun yang mengaku mempunyai teman pernah melakukan hubungan seksual pra nikah masing-masing mencapai $48,6 \%$ dan $46,5 \%$ (SKRRI, 2003).

Tingginya tingkat perilaku seksual beresiko tinggi di kalangan remaja dan gejala semakin permisifnya budaya seks bebas yang terungkap dari beberapa hasil penelitian patut menjadi perhatian dan keprihatinan kita bersama. Alangkah tidak bijak apabila kita hanya menyalahkan remaja dalam berbagai fenomena yang muncul sekarang ini. Harus disadari bahwa remaja saat ini berada dalam situasi dan kondisi yang penuh dengan godaan, tantangan dan bahaya yang lebih besar dan kompleks dibandingkan dengan remaja zaman dulu. Era Revolusi Industri 4.0 yang ditandai dengan kuatnya arus globalisasi dan kecanggihan teknologi dimana tawaran kemudahan dalam mengakses informasi tanpa ada batasan apapun menjadi sebuah tantangan tersendiri bagi remaja 
dalam memenuhi rasa keingintahuannya tentang berbagai hal, termasuk hal-hal yang berkaitan dengan seksualitas manusia.

Berkaitan dengan hal tersebut, pemberian layanan bimbingan berbasis kesehatan reproduksi perlu diberikan kepada remaja. Hal ini dimaksudkan supaya remaja tidak mencari informasi yang salah mengenai seksualitas manusia. Widad (2001) mengemukakan bahwa faktor utama merebaknya seks bebas di kalangan remaja adalah besarnya rasa ingin tahu remaja tentang seks, hanya saja rasa penasaran itu tidak didasari oleh informasi tentang kesehatan reproduksi yang benar dan bertanggung jawab. Melalui layanan bimbingan kesehatan reproduksi remaja diharapkan dapat terbangun pemahaman dan keterampilan perilaku seksual yang sehat dan bertanggung jawab.

\section{METODE}

Penelitian ini menggunakan pendekatan kualitatif dan kuantitatif. Creswell (1994: 177) menyebutkan tiga model desain kombinasi kualitatif-kuantitatif, yaitu: two-phase design, dominant-less dominant design dan mixed methodology design. Karena dalam penelitian ini terdapat dua data, yakni kualitatif dan kuantitatif yang saling mendukung, maka dipilih mixed methodology design. Pendekatan kuantitatif digunakan untuk memotret profil perilaku seksual siswa dan keefektifan layanan bimbingan. Sedangkan pendekatan kualitatif digunakan untuk mendeskripsikan pelaksanaan layanan bimbingan dan untuk memperoleh gambaran upaya guru bimbingan dan konseling dalam mengembangkan perilaku seksual siswa. Polulasi penelitian ini siswa SMA kelas $X$ berjumlah 250 orang dengan sampel 30 orang berdasarkan hasil angket perilaku seksual dengan melihat perolehan rerata kelas paling rendah.

\section{HASIL DAN PEMBAHASAN}

\section{Profil Perilaku Seksual Remaja}

Secara umum perilaku seksual siswa berada pada taraf waspada (36\%) menuju perlu pengembangan $(31 \%)$. Hal ini menunjukan adanya kecenderungan perilaku seksual berisiko tinggi di kalangan remaja. Sebagai kecenderungan, perilaku seksual berisiko tinggi pada remaja dapat saja meningkat atau menurun meski demikian kecenderungan untuk meningkat akan lebih besar. Dengan asumsi perilaku seksual merupakan bagian yang sangat privasi, dianggap tabu untuk diperbincangkan secara umum, pengaruh media pornografi yang begitu kuat dan mudah diakses, kondisi psikologis remaja yang masih labil, pengaruh teman sebaya, dan seringkali menjadi fenomena gunung es. Jika remaja tidak diberikan bimbingan yang mengarahkan pada perilaku seksual sehat, maka perilaku seksual remaja dapat menjadi tidak sehat bahkan menyimpang.

Kecenderungan perilaku seksual berisiko tinggi di kalangan remaja tidak dapat diabaikan begitu saja, karena ada indikasi bahwa perilaku seksual berisiko tinggi remaja telah menjadi fenomena gunung es. Untuk tujuan pendidikan nasional, perilaku seksual berisiko tinggi di kalangan remaja jelas merupakan suatu fenomena yang cukup meresahkan. Sebab sangat mustahil dapat terbentuk kepribadian peserta didik yang berakhlak mulia, mandiri, memiliki kekuatan spiritual keagamaan, pengendalian diri, serta memiliki keterampilan yang diperlukan diri, masyarakat, bangsa dan negara jika perilaku seksual berisiko tinggi di kalangan remaja terus dibiarkan berkembang. 


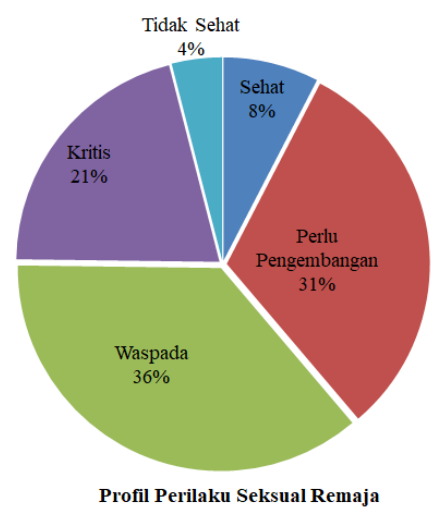

Gambar 1. Diagram Profil Umum Perilaku Seksual Remaja

Posisi perilaku seksual dalam taraf waspada menuju perlu pengembangan dapat dimaknai bahwa sebagian besar siswa memiliki perilaku seksual berisiko tinggi. Bentuk perilaku seksual berisiko tersebut diantaranya: belum dapat terbuka kepada orang tua terkait dengan perasaan cinta, memilih media internet atau majalah orang dewasa untuk memenuhi rasa ingin tahu tentang seksualitas manusia, terkadang menyalurkan dorongan seksual dengan melihat gambar porno, film porno, dan melakukan onani atau masturbasi, merasa sulit bersikap tegas (asertif) menolak ajakan teman atau pacar untuk melihat media pornografi, seringkali menahan atau menyembunyikan perasaan cinta, kurang memiliki kepercayaan diri, kadangkala melakukan petting, bermesraan ditempat umum, berpakaian ketat ketika keluar rumah dan seringkali menggunakan kata-kata mesum untuk menggoda orang lain.

Untuk perilaku seksual sehat berarti siswa memiliki kecenderungan perilaku untuk menjaga kebersihan pakaian dalam, menghindarkan diri dari obat pemutih wajah atau kulit, selalu membersihkan kemaluan setelah buang air kecil, mimpi basah dan menstruasi, menceritakan perasaan cinta kepada orang tua, menahan diri untuk mencium atau dicium pacar, menghindarkan diri dari media-media pornografi, tidak pernah melakukan onani/masturbasi, menghindarkan diri dari berduaan ditempat sepi dengan pacar, selalu mengenakan pakaian sopan ditempat umum, menghindari candaan yang mengarah pada seks, menghindari pengaruh teman atau pacar untuk melihat media pornografi, memiliki keyakinan akan menemukan pasangan hidup seperti yang diharapkan, menahan diri untuk selalu tampil mengikuti mode, mengakui secara terbuka perasaan cinta dan menghindarkan diri untuk melakukan hubungan seksual.

Pada taraf kritis dan tidak sehat, siswa cenderung berperilaku tidak memperdulikan kebersihan pakaian dalam, seringkali mengakses media pornografi, menyimpan film porno di Handphone, menggoda teman atau pacar dengan kata-kata mesum, seringkali becandaan mengarah pada seks, berduaan memadu cinta ditempat sepi, merasa sulit terbuka dengan orang tua terkait dengan permasalahan cinta dan seksual, lebih memilih teman atau pacar untuk berbagi cerita, merasa dendam ketika cinta ditolak, seringkali mengutamakan penampilan fisik untuk menarik perhatian, memakai pakaian seksi ditempat umum, mengulang-ulang untuk melakukan onani/masturbasi, merasa sulit menolak ajakan teman atau pacar untuk melihat media-media pornografi dan seringkali melakukan petting.

Selain itu, berdasarkan hasil observasi dan wawancara dengan guru bimbingan dan konseling di sekolah yang menjadi tempat penelitian juga ditemukan gambaran perilaku 
seksual siswa, seperti: siswa selalu berhenti di depan cermin untuk melihat dirinya sendiri, mengusap wajah atau tersenyum sendiri di depan cermin, membawa cermin di dalam kelas dan bercermin pada saat proses belajar mengajar berlangsung, berpelukan pada saat berboncengan motor, bergandengan tangan pada saat jalan berdua, dan beberapa siswa didapati menyimpan film porno di handphone bahkan ada siswa putri yang hamil dan keguguran di sekolah.

Hasil penelitian ini sejalan dengan temuan Natasha (2004) menunjukan perilaku seksual berisiko tinggi remaja SMP dan SMU (usia 13-18 tahun) di Bayongbong Garut, antara lain: pernah berciuman bibir (3,8\%), menonton film porno dengan teman $(3,6 \%)$, menonton film porno sendiri $(2,3 \%)$, mencium leher $(2,1 \%)$, saling meraba bagian tubuh yang sensitive $(2,1 \%)$, melihat situs porno di internet $(1,3 \%)$, menonton film porno dengan pacar $(0,8 \%)$, melakukan oral seks $(0,5 \%)$, petting $(0,5 \%)$, masturbasi $(0,5 \%)$, dan 5 responden melakukan hubungan seks (1,3\%). Studi mutiara,dkk (2009) tentang gambaran perilaku seksual mahasiswa usia 18-24 tahun di Jatinangor menunjukan sebanyak 100\% berpegangan tangan dengan pacarnya, $90 \%$ berpelukan, $82 \%$ necking, $56 \%$ meraba bagian tubuh yang sensitif, 52\% petting, 33\% oral seks, dan 34\% sexual intercourse. Begitu juga hasil survei Komisi Perlindungan Anak Indonesia (2010) pada remaja usia SMP dan SMA berjumlah 10.833 orang di 12 kota besar menunjukan sebanyak $99 \%$ menyatakan pernah berciuman, $77 \%$ pernah melakukan peting, 32\% melakukan hubungan seksual dan 20\% remaja putri pernah melakukan aborsi. Kota dengan angka tertinggi secara berurutan: Jakarta, Bandung dan Surabaya. Selain itu, hasil survey Wahdah Islamiyah (2008) terhadap remaja umur 15-24 tahun di 33 propinsi di Indonesia juga menyebutkan 63\% pernah melakukan hubungan seks diluar nikah, $21 \%$ remaja putri melakukan aborsi dan $87 \%$ pernah menonton film porno.

Sementara itu penelitian Suryoputro, Ford, dan Shaluhiyah (2006) menyebutkan bahwa lebih dari $75 \%$ responden umur pertama kali melakukan hubungan seksual adalah kurang dari 18 tahun. Mengingat rentang usia remaja di sekolah menengah atas (SMA) adalah 16-18 tahun, hal ini menunjukkan bahwa hubungan seksual pertama mereka kebanyakan terjadi pada masa sekolah menengah atas atau sebelumnya. Hasil penelitian Adikusuma (2007) menemukan sebanyak 88,33\% remaja ingin melakukan hubungan seks tetapi takut risiko dan sebanyak $26,26 \%$ menyatakan cara terbaik untuk memenuhi kebutuhan seksual adalah dengan berhubungan seks. Meskipun demikian, dalam penelitian Adikusuma tersebut terungkap bahwa semua responden (100\%) menyatakan hubungan seksual pada masa remaja hendaknya dihindari.

Berdasarkan pemaparan hasil penelitian di atas, secara nyata menunjukan bahwa usia remaja sangat rentan dengan perilaku seksual berisiko. Pada masa ini hampir dapat dipastikan setiap remaja memiliki keinginan untuk melakukan hubungan seksual. Hal ini sejalan dengan pendapat Freud (Hurlock, 1980) yang mengemukakan bahwa pada masa remaja libido atau energi seksual remaja menjadi hidup, yang sebelumnya laten pada masa pra remaja. Oleh karena itu muncul hasrat dan dorongan untuk menyalurkan keinginan seksualnya. Lebih jauh Hurlock (1980) menyebutkan bahwa bentuk perilaku seksual remaja yang paling awal adalah eksplorasi. Rasa ingin tahu mengakibatkan adanya eksplorasi. Eksplorasi memiliki dua bentuk, yaitu secara intelektual dan teknik manipulasi. Secara intelektual akan menuntun remaja untuk menanyakan hal-hal tertentu. Ketika remaja tidak berani atau malu bertanya, maka mereka akan mencari tahu melalui buku, majalah, internet dan media lainya untuk mendapatkan jawaban dari setiap pertanyaanya. Apabila remaja tidak dapat memenuhi rasa ingin tahunya secara langsung 
melalui pendekatan intelektual, mereka akan melakukan pendekatan secara langsung yang melibatkan teknik manipulasi, yaitu dengan cara mengeksplorasi organ seksnya sendiri dan organ seks orang lain.

Menurut Myles (1993) seksualitas merupakan proses yang berlangsung secara terusmenerus sejak seorang bayi lahir sampai meninggal yang memperlihatkan hubungan erat antara aspek fisik (sistem reproduksi) dengan aspek psikis dan sosial yang muncul dalam bentuk perilaku dan merupakan bagian integral dari kehidupan manusia. Pengertian dari Myles tersebut menunjukkan bahwa dimensi seksualitas sangatlah luas meliputi bukan saja dimensi fisik namun juga psikis dan sosial. Hal senada juga disampaikan oleh Steinberg (2002) yang menyebutkan masa remaja merupakan masa transisi anak-anak yang belum matang menuju masa dewasa yang matang. Dalam masa peralihan ini, remaja mengalami transisi pada aspek biologis, kognitif dan sosial. Secara biologis remaja mengalami pertumbuhan yang dramatis; mereka menjadi lebih besar dan lebih tinggi, mampu bereproduksi karena organ-organ kelamin atau organ reproduksinya telah matang. Pada aspek psikologis, remaja lebih matang dalam membuat keputusan, dapat berfikir tentang konsep-konsep abstrak termasuk didalamnya mampu berfikir secara hipotetik. Secara sosial, mereka telah membina hubungan khusus dengan lawan jenis atau berpacaran.

Dalam pandangan Piaget (Papalia et al., 2001), meskipun remaja telah mempunyai kematangan kognitif, namun dalam kenyataan mereka belum mampu mengolah informasi yang diterima dengan benar. Akibatnya perilaku seksual remaja sering tidak terkontrol dengan baik. Selain itu, rasa ingin tahu yang besar untuk mencoba segala hal yang belum diketahui sangat mempengaruhi remaja melakukan perilaku seksual aktif beresiko, karena pada umumnya remaja ingin mengetahui banyak hal yang hanya dapat dipuaskan serta diwujudkannya melalui pengalaman mereka sendiri (learning by doing).

Perilaku seksual remaja selain terdorong oleh kematangan organ seksual dan perkembangan hormon seksual, juga dipengaruhi oleh berbagai faktor melalui interaksi sosial. Remaja sebagai individu transisi dalam masa perkembangan sense of identity vs role confusion akan menghadapi tantangan hidup yang lebih besar pada era teknologi informasi seperti sekarang ini. Dunia teknologi informasi menyajikan segala kemudahan informasi (positif dan negatif) masih menjadi pilihan favorit bagi remaja untuk memenuhi rasa keingintahuan mereka termasuk masalah seksualitas manusia. Akibatnya banyak remaja yang keliru dalam memahami proses reproduksi dan seputar masalah seksualitas manusia. Ada remaja yang beranggapan bahwa melakukan onani/masturbasi akan menyehatkan badan, berenang dikolam yang tercemar sperma dapat mengakibatkan kehamilan, meloncat-loncat setelah berhubungan seksual tidak akan menyebabkan kehamilan, berhubungan seksual sekali tidak akan menyebabkan kehamilan. Pemahaman yang salah akan mengakibatkan semakin meningkatnya kehamilan tidak diinginkan (KTD) di kalangan remaja.

Selain itu, pencitraan media melalui bebagai iklan produk maupun acara-acara tertentu yang mengangggap kecantikan dan ketampanan dari segi fisik, pakaian yang vulgar, gaya hidup hedonis cukup berkontribusi terhadap gaya berfikir remaja mengenai konsep hidup. Belum lagi semakin permisifnya budaya seks bebas, kemudahan mengakses pornografi, kurangnya perhatian orang tua terhadap remaja, perhatian yang berlebihan dari orang tua kepada remaja, ketidakpercayaan antara orangtua kepada remaja, tekanan teman sebaya juga ikut mendorong semakin meningkatnya perilaku seksual beresiko tinggi di kalangan remaja. 


\section{Strategi Intervensi dan Upaya Guru BK}

Strategi layanan yang dilakukan untuk mengembangkan perilaku seksual sehat adalah melalui strategi pelayanan bimbingan kelompok. Kegiatan ini terdiri dari delapan sesi, yaitu: (1) sistem dan proses reproduksi manusia, (2) proses, akar masalah dan risiko aborsi, (3) penyakit menular seksual akibat seks bebas, (4) be an assertive teenager, (5) asyiknya bersahabat dengan guru, orang tua dan tenaga proffesional, (6), Pornografi Rusak Otak Melebihi Narkoba (7) Biarkan Semua Indah Pada Waktunya, (8) menjadi remaja smart, berprestasi dan sukses hidup.

Adapun teknik pelayanan yang digunakan, seperti: diskusi, bermain peran (role playing), pelatihan motivasi, pemutaran fim aborsi, pemutaran film body atlas: in the womb/sex, pemutaran film tukirah, pemutaran film vertical limite dan pemutaran film Hero. Pada setiap akhir sesi siswa diberikan blangko evaluasi dengan tujuan untuk mengetahui pemahaman dan internalisasi materi yang telah diberikan serta mengetahui sikap atau perilaku apa yang akan mereka kembangkan setelah mendapatkan pemahaman dari materi yang diberikan. Siswa diharapkan dapat memanfaatkan dinamika kelompok untuk memperoleh gambaran situasi tertentu, sehingga dapat terampil mengambil keputusan manakala dihadapkan pada situasi yang sebenarnya.

Berdasarkan hasil wawancara dengan Koordinator bimbingan dan konseling dan beberapa guru bimbingan dan konseling di tempat penelitian, diketahui bahwa penanganan masalah perilaku seksual siswa bersifat layanan responsif mengarah pada kuratif. Beberapa upaya yang telah dilakukan oleh guru bimbingan dan konseling diantaranya: (1) melakukan razia mendadak untuk mengetahui siswa yang membawa media-media pornografi atau alat kontrasepsi; (2) menahan barang bukti yang ditemukan untuk diserahkan kepada orang tua/wali siswa; (3) mengundang orang tua/wali siswa yang terbukti membawa media pornografi untuk diberikan pembinaan dirumah dan di sekolah; (4) memberikan nasihat, peringatan dan skorsing apabila siswa sudah 3 kali atau lebih terbukti membawa media pornografi atau alat kontasepsi; (5) memberikan hukuman berupa kewajiban mengenakan pakaian muslim (memakai jilbab) kepada siswa perempuan muslim yang terbukti membawa film porno atau menyimpan di hand phone; dan (6) mengeluarkan dari sekolah bagi siswa perempuan yang hamil.

\section{Hasil Uji Efektivitas}

Secara umum program bimbingan dan konseling pribadi-sosial efektif untuk mengembangkan perilaku seksual remaja. Meski demikian, tidak semua aspek dan indikator perilaku seksual siswa menunjukan peningkatan yang signifikan antara sebelum dan sesudah pemberian pelayanan bimbingan. Dari tiga aspek (fisik, psikologis dan sosial) perilaku seksual sehat siswa, dua aspek yaitu pada aspek psikologis dan sosial terjadi peningkatan yang cukup signifikan antara nilai pre-test dan post-test. Sedangkan pada aspek fisik, tidak terjadi peningkatan yang signifikan antara sebelum dan sesudah pemberian pelayanan bimbingan. Hal ini berarti layanan bimbingan kesehatan reproduksi remaja efektif untuk mengembangkan perilaku seksual siswa pada aspek psikologis dan sosial serta kurang efektif untuk mengembangkan perilaku seksual sehat secara fisik.

Kekurangefektifan di atas terindikasi kuat karena skor awal (pre-test) pada aspek fisik sudah menunjukan angka yang cukup tinggi. Artinya siswa secara umum memiliki perilaku seksual sehat secara fisik, seperti: menjaga kebersihan bagian tubuh yang 
menjadi daya tarik seksual, merawat kebersihan organ reproduksi, dan tidak melakukan hubungan seks sebelum menikah.

Pada aspek psikologis untuk indikator merasakan ketertarikan dengan lawan jenis perolehan skor pre-test juga menunjukan angka yang cukup tinggi, yaitu pada taraf perlu pengembangan $(40,79 \%)$. Artinya sebagian besar siswa dapat mengelola perasaan tertarik dengan lawan jenis melalui cara-cara yang sehat dan bertanggung jawab.

Pada aspek sosial untuk indikator memakai pakaian sopan ditempat umum, menahan diri kontak fisik dengan maksud menggoda dan menahan diri bermesraan ditempat umum hasil pre-test menunjukan perilaku seksual untuk ketiga indikator tersebut masing-masing berada pada kategori perlu pengembangan $(54,15 \%)$, perlu pengembangan $(66,42 \%)$ dan Kategori sehat $(40,79 \%)$. Hal ini berarti sebelum diberi pelayanan bimbingan sebagian besar perilaku seksual siswa memiliki perilaku seksual yang cukup sehat. Sedangkan pada kategori menahan diri berkata-kata mesum, tidak menunjukan kenaikan angka yang signifikan, padahal hasil pre-test perilaku seksual siswa berada pada taraf waspada sebesar $44,04 \%$. Hal ini mengindikasikan berkata-kata mesum sudah mulai dianggap hal biasa dilingkungan sosial remaja.

Hasil uji coba keefektifan layanan kesehatan teproduksi remaja ini sesuai dengan target sasaran yang secara spesifik lebih ditekankan pada pengembangan perilaku seksual sehat secara psikologis dan sosial. Indikator yang menunjukan keefektifan layanan kesehatan reproduksi remaja untuk mengembangkan perilaku seksual sehat siswa adalah menahan diri untuk melihat media pornografi, tidak ada tekanan psikologis akibat cinta dan berani menampilkan perilaku asertif.

\section{SIMPULAN}

Perilaku seksual siswa secara umum berada pada taraf waspada menuju perlu pengembangan. Hal ini membuktikan masa remaja merupakan masa rawan terhadap perilaku seksual berisiko tinggi. Perilaku seksual berisiko pada aspek sosial, yaitu: tidak dapat menampilkan perilaku asertif; aspek psikologis: tidak dapat menahan diri untuk melihat media pornografi; dan pada aspek fisik: pengalaman melakukan hubungan seksual. Penanganan masalah perilaku seksual ditempat penelitian bersifat layanan responsif menuju kuratif dengan pendekatan reaktif-sporadis. Penegakan disiplin yang terpusat pada guru masih menjadi faktor dominan dalam menangani permasalahan siswa. Layanan KRR dirumuskan sesuai dengan kebutuhan pokok siswa, yaitu pada aspek psikologis dan sosial. Strategi bimbingan dilaksanakan melalui bimbingan kelompok secara klasikal. Fokus layanan diarahkan pada upaya preventif dengan memanfaatkan dinamika kelompok dan internalisasi materi pelayanan yang telah diberikan. Teknik yang digunakan dalam pelayanan bimbingan diantaranya: bermain peran (role playing), pemberian materi yang dikolaborasikan dengan gambar-gambar yang relevan dan pemutaran video yang mendukung untuk penyampaian materi. Struktur dan komponen program layanan mengacu pada paradigma baru bimbingan dan konseling komprehensif dengan pendekatan yang berorientasi pada pencegahan dan pengembangan (preventive and development). Layanan KRR efektif untuk mengembangkan perilaku seksual remaja. Meski demikian, tidak semua aspek dan indikator perilaku seksual siswa menunjukan peningkatan secara signifikan. Layanan KRR teruji efektif untuk mengembangkan perilaku seksual sehat pada aspek psikologis dan sosial serta kurang efektif untuk mengembangkan perilaku seksual sehat secara fisik. 


\section{REFERENSI}

Arief, K. (2002). Remaja, kesehatan reproduksi dan pendewasaan usia perkawinan. Jakarta: Bagian Proyek Pendidikan Kesehatan Reproduksi Remaja Pusat Pengembangan Kualitas Jasmani Departemen Pendidikan Nasional.

Borders, L. D., \& Drury, S. M. (1992). Comprehensive school counseling programs: A review for policymakers and practitioners. Journal of Counseling $\mathcal{E}$ Development, 70(4), $487-498$

Cresweell, J. W. (1994). Research design qualitative \& quantitative approaches. Thousand Oaks, California: SAGE Publications.

Cresweell, J. W. (2008). Educational research: Planning, conducting and evaluating quantitative and qualitative research. New Jersey: Pearson Education.

Hasmi, E., et al. (2001). Membantu remaja memahami dirinya. Jakarta: Direktorat Remaja dan Perlindungan Hak-Hak Reproduksi BKKBN.

Hurlock, E. B. (1980). Psikologi perkembangan (Alih bahasa, Istiwidayanti dan Sudjarwo, 1980). Jakarta: Erlangga.

Pikiran Rakyat, 3 April 2009. Kecanduan Pornografi Rusak Otak Melebihi Narkoba.

Santrock, J. W. (2002). Life span development: Perkembangan masa hidup (Alih bahasa, Achmad Chusairi dan Juda Damanik). Jakarta: Erlangga.

Santrock, J. W. (2003). Adolescence: Perkembangan remaja (Alih bahasa, Shinto B. Adelar dan Sherley Saragih). Jakarta: Erlangga.

Setyawati, V. (2007). Menjawab pertanyaan anak soal seks. Yogyakarta: ANDI Offset.

Steinberg, L. (2002). Adolescence. New Baskerville: McGraw-Hill.

Suryoputro, A., Ford, N. J., \& Shaluhiyah, Z. (2006). Faktor-faktor yang mempengaruhi perilaku seksual remaja di jawa tengah: Implikasinya terhadap kebijakan dan layanan kesehatan seksual dan reproduksi. Makara Kesehatan, 10(1), 29-40.

Yusuf, S. (2007). Psikologi perkembangan anak dan remaja. Bandung: Remaja Rosdakarya.

Yusuf, S., \& Nurihsan A. J. (2007). Landasan bimbingan dan konseling. Bandung: Remaja Rosdakarya.

Yusuf, S., \& Nurihsan A. J. (2009). Program bimbingan dan konseling di sekolah. Bandung: Rizqi Press. 